\title{
On the Economic Health of Vietnam's Construction Industry
}

\author{
Tristan Nguyen \\ Fresenius University, Munich, Germany \\ Trung Dung Doan \\ Berlin School of Economics and Law, Berlin, Germany
}

\begin{abstract}
This paper analyzes the economic health of Vietnam's construction industry. The sample data have been collected from 32 construction companies listed on Ho Chi Minh Stock Exchange during 2013 to 2014. Their financial reports have been taken into account to examine the business condition by using the Altman Z-score Model and the Emerging Market Model. In these two models, the impact of Growth, Tangibility, Debt Ratio, Size and Cash Conversion Cycle are proved to be negative in relation with the firm's performance in the original Z-sore. We find out in our analysis that the Emerging Market Model is the more appropriate model for assessing the health of Vietnam's construction firms. In addition, further hypothesis tests are conducted to provide a regression analysis of the correlation between the Z-score and the five factors mentioned above. The regression has revealed that none of these factors has positive or negative impacts on Vietnam's construction enterprises.
\end{abstract}

Keywords: firm's performance, Z-Score, emerging market, Vietnam's construction industry, firm's bankruptcy.

\section{INTRODUCTION}

Since the integration of the World Trade Organization (WTO) in 2007, there have been significant changes in many business aspects in Vietnam. Vietnamese enterprises are taking advantage of new opportunities to expand their business across borders to exchange skilled workers and knowledge. Within the process of integration, Vietnam's construction industry has accomplished many targets and effectively contributes to Vietnam's economic growth. Many transportation projects have been built rapidly such as the Railway/Metro system, highways, hydropower, hotels and apartments. Many international standards of material, design and construction techniques have been progressively implemented into the construction projects with advanced equipment for survey and design. Labor skills and knowledge have been improved as required by advanced technologies and construction techniques.

Although Vietnam's construction industry has witnessed great progress in advanced technology, technical development, and the quality of skills and knowledge, the integration of the WTO has also brought with it numerous obstacles and challenges. The traditional business environment prior to the WTO had been protected by Vietnamese Law and through regulations in taxation, transactions, imports and exports. Since 2008, multinational enterprises have considered the WTO as a good opportunity to expand their business into Vietnam, as the result, local enterprises have been facing multiple difficulties to deal with the new competition. This has increased the probability of bankruptcy of Vietnam's construction firms which fail to cope with the new market situation. The problem of bankruptcy can be the result of poor management, inappropriate sales prediction, failure of management in identifying customers' preferences and failure to adapt advanced technologies. At present market, managements are 
seeking methods to predict financial distress in order to avoid mistakes in financing, investing and also to ensure the sustainable development of their businesses.

One of the most important tools to assess the economic health of a firm is the Altman Z-Score. The formula analyzes the probability that a firm could go bankrupt within two years. It uses multiple values from the corporate income and balance sheet to measure the economic health of a company. However, the economic health of the firm is also presented in detail by other financial information in the financial report. In this paper, we focus our research on the relationship between financial information and business' performance measured by Altman's Z-Score in order to provide practical insights in assessing business failure in Vietnam's construction industry.

\section{Research Objective}

\section{RESEARCH OBJECTIVE AND METHODOLOGY}

The construction industry is a distinctive business sector with its unique characteristics. In fact, the construction industry plays an important role in the Vietnamese economy as it attracts many foreign investments (Dang and Pheng, 2015). There has been a positive growth in recent years in laws and regulations due to the change in Vietnamese government, low interest rates and the falling price of building material. However, the construction industry has failed to provide financial transparency to all investors. This paper will explore Vietnam's construction industry as the main objective of information research to measure financial health based on the correlation between internal financial information and the Altman Z-score. Additionally, the information collected will be analyzed to find out whether the Altman Z-score is applicable to predict business failure in Vietnam.

The findings of this research will contribute to assisting the Vietnamese government to be aware of potential risk in targeting globalization and the effect of investment attraction into Vietnam. The result will signify the level of risk in construction businesses as well as the construction industry as a whole. Our research also provides Vietnamese construction enterprises an overview of the construction industry in the process of globalization. This will enhance business development strategy to prepare to compete with multinational enterprises. Foreign investment and other enterprises can adapt our findings as references to implement business strategy that fit into the Vietnamese market and regulations.

\section{Research Methodology}

Information from Vietnam's stock market will be collected for the data analysis, including all information about the construction industry, 32 publicly listed construction companies and their financial report from 2013 to 2014. This includes working Capital, Total Assets, Retained Earnings, Earnings before Interest and Taxes, Market Value of Equity, Total Liabilities, Sales, Current Assets, Fix Assets, Equity, Preferred Shares and some other important factors.

The structure of this paper will be based on a regression analysis to examine the factors that can have an impact on the financial health of businesses. For the purpose of this research, some assumptions will be pointed out to test the correlations of the following indicators:

1. Company Financial Growth;

2. Tangibility and its correlation to the company wellbeing;

3. Cash Conversed Circle and its relation to company wellbeing;

4. Size of the organization;

5. Debt ratio, the negative effect to the organization. 


\section{Define the concept of "Failure"}

\section{LITERATURE REVIEWS AND HYPOTHESIS}

The bankruptcy of Lehman Brothers in 2008 has led to the largest business failure in United State history (Chieng 2013), which affects the whole financial system worldwide. Many academic researchers have emphasized the need of failure definition in order to recognize a firm's economic health. However, the topic remains unclear when it comes to the common definition of "Failure." In the absence of such a common definition, it is difficult to develop the appropriate model to assess a business' wealth and condition in accordance with a specific system and industry.

Altman and Narayanan (1977) asserted that the definition of firms' failure can be diverse in different forms, but mostly depends on the business environment. Thus, firms which are unable to adapt to changes in business environment can be "weeded out" in the form of bankruptcy, bond default, government intervention and liquidation. Pretorious (2009) gave an in-depth definition of "decline and failure" to guide academic researchers to approach the applicable prediction model. According to Siddiqui (2012), bankruptcy prediction can be conducted by various models such as Logit \& Probit Analysis, Recursive Partitioning Algorithm and Neural Network. Combining all the historical development of business failure analysis, Wong and Ng (2010) have concluded that the concept of business failure in the construction field can be defined and subdivided into two different categories:

- Technical \& Financial Capability which indicates the capability of a business to cope with the natural environment of the business market using internal core competencies.

- Environment Determinant which indicates the external factors that affect the well-being of an organization such as government law and regulation, economic conditions and excessive competition within the market.

Focusing on a financial perspective, Enshassi (2006) and McKay (2016) both emphasized the financial soundness of a business as a result of losses to creditors after foreclosure or attachment, unpaid debts or involvement in court action. This is the case when there is a high rate of uncollectable debt; the company voluntarily files for bankruptcy while at the same time they cannot earn adequate returns. Ucbasaran et al. (2013) believe that business failure can be defined even before the establishment of a business. In their opinion, the indication of a failing business is the failure to provide reasonable income for owners and an unfair rate of return to investors. The study of business failure has also exposed the cause of the degradation process of an entity, in which potential failure can be tackled before actual failure (Torres-Coronas et al., 2015). This has led to many studies designing the corrective measurement to escape business failure which can be called a predictive stage (Beaver 1966 and Altman 1968).

\section{The original formula of the Z-score (Model 1)}

In all aspects of business, the term "bankruptcy" has been a natural concept regarding business failure to endure current operation with its own debt obligation. In many studies, bankruptcy is a significant factor that influences the benefit of investors and the economy's well-being. The forecast of financial insolvency is highly appreciated as evidence in many developed countries. In classical theories, finance difficulty is a form of failure in a creditor's meeting process (Altman, 1968), the maturity of liability payment (Ohlson, 1980), corporate ongoing concern (Zmijewski, 1984) or at the state of liquidation (Taffler, 1984 and Mckee, 2000) and the increasing of debt ratio (Beaver, 1966). Bankruptcy prediction before business failure can help a company by securing its financial distress and taking necessary actions to reduce risk and even avoid bankruptcy. This is also an important tool for investors to measure the risk of their investment in firms that are vulnerable to bankruptcy. 
The Altman's formula was used to forecast the likelihood of bankruptcy of a firm within two years, signal corporate default and measure a firm's financial distress. According to Altman (2013), the ratio analysis can be misleading as the method was fundamentally univariate, which emphasizes one individual signal of forthcoming problems. Altman indicated that the more appropriate analysis technique to predict bankruptcy is the multiple discriminant analysis (MDA) by Fisher (1936). Altman customized Fisher's technique and applied it to financial areas by using statistical information to observe, classify, and predict problems. Thus, he formulated the following formula of the Z-score:

$$
\mathrm{Z}=0.012 * X 1+0.014 * X 2+0.033^{*} \mathrm{X} 3+0.006 * X 4+0.999 * X 5
$$

Where:

$\mathrm{X} 1$ = Working capital / Total assets;

$\mathrm{X} 2$ = Retained earnings / Total Assets;

X3 = Earnings before interest and taxes / Total Assets;

$\mathrm{X} 4$ = Market value equity / Book value of total equities;

$\mathrm{X} 5$ = Sales / Total assets;

$\mathrm{Z}=$ Overall index.

The interpretation of the Z-score Model:

\begin{tabular}{|l|l|}
\hline Z score $>2.99$ & "Safe" zone \\
\hline $1.81<$ Z score $<2.99$ & "Grey" zone \\
\hline Z score $<1.81$ & "Distress" zone \\
\hline
\end{tabular}

\section{X1: Working capital / Total Assets (WC/TA)}

The ratio is regularly found in the study of business corporate performance. In most cases, the ratio is considered as a tool to test the liquidity of all working capital. It is the measure of a firm's capability to convert its short-term assets to cash in order to meet short-term obligations. Since the ratio reveals the percentage of outstanding liquid assets compared with the company's total assets. In normal terms, the current assets tend to decrease compared with total assets when businesses have difficulty in liquidation or operating loss. In other aspects, the company's liquidity improvement over time will increase the ratio of Working Capital/Total Assets. There are two other tests of liquidity such as the Acid test (quick ratio) and Current Ratio. However, they are less helpful to test the failing condition of firms.

\section{X2: Retained earnings / Total Assets (RE/TA)}

As a part of the Z-score Model, the ratio RE/TA represents a cumulative account which is an indicator for reinvestment by using the earnings during the financial period. At the end of the fiscal year, the company will use these net earnings to reinvest or to pay off their debt. This ratio shows investors how much a company relies on debt (the smaller the ratio, the higher is the debt ratio of the company). It can be argued that this perception can be biased when it comes to new firms and the chance to be classified as a critical position is high. But it is indeed a real-world situation as more than $50 \%$ of new companies that went bankrupt in their first 5 years (Robinson, 2014).

\section{X3: Earnings before interest and taxes / Total Assets (EBIT/TA)}

This ratio is also called return on total assets (ROTA) which is calculated as a fraction of a company's earnings before interest and taxes (EBIT) against its total net assets. The ratio is an indicator of how effectively a company can use its existing assets to generate earnings before 
contractual obligations must be paid. The higher this ratio, the more effectively a company can use its assets.

\section{X4: Market value equity / Book value of total equities (MVE/BVTE)}

Market value of Equity or market capitalization is the combination of both preferred and common stock while liabilities include long and short terms. Investors can explore the firm's assets by assessing the stock market which is the measurement of a firm's value and tackle any potential pending problems through price changes when a firm's liabilities exceed its assets. According to Altman (2013), this ratio delivers a more effective forecast of financial distresses than net worth/ total debt (Book value).

\section{X5: Sales / Total assets (S/TA)}

As an indicator of sales performance, this ratio is an important instrument to indicate sales turnover measurement in any market. It designates the efficiency and effectiveness of assets used to conduct sales. According to Altman (2013), this ratio became one of the most important variables as it has a "unique relationship to other variables in the model" which has a significant impact on the overall discriminating ability of results.

\section{The Emerging Market Score Model (EM Z-score) (Model 2)}

For the Emerging Market Score Model, we use the following formula:

$$
\mathrm{Z}=3.25+6.56 * \mathrm{X} 1+3.26 * \mathrm{X} 2+6.72 * \mathrm{X} 3+1.05 * \mathrm{X} 4
$$

Where:

X1 = Current Assets - Current Liabilities / Total Assets

X2 = Retained earnings /Total Assets

$\mathrm{X} 3$ = Earnings before interest and taxes / Total Assets

$\mathrm{X} 4$ = Book Value of Equity / Total Liabilities

The interpretation of Emerging Market Score Model:

\begin{tabular}{|l|l|}
\hline EM Z - score $>2.60$ & "Safe" zone \\
\hline $1.1<$ EM Z - score $<2.60$ & "Grey" zone \\
\hline EM Z - score $<1.1$ & "Distress" zone \\
\hline
\end{tabular}

\section{The empirical results and analysis}

The study includes three categories. First, the report will use 32 construction companies listed in the Vietnam Stock Market from 2013 to 2014. Second, the organized data from 32 construction companies will be calculated in the Z-score Model and the EM Z-score Model and be applied to the main methodology. Lastly, the CICB Credit database (The State Bank of Vietnam) which provided integrated information on credit activities, information about credit relations and assets securing loans.

In order to find the better model that statistically applies to the Vietnam Construction Industry, the CICB will be used as a significant guideline to measure the percentage of matching variables that are close to publicly listed firm's conditions. Applying the Z-score Model and EM Z-score Model for the sample of 32 construction companies from 2013 to 2014, the results are represented in Table 1: 


\begin{tabular}{|c|c|c|c|c|c|c|c|c|c|}
\hline & & & Z-score & Model 1] & & & I Z-scor & (Model 2) & \\
\hline & rms & & 13 & & & 201 & & 201 & \\
\hline & & Z-score & Classifica & Z-score & Classifica & EM Z-score & Classific & EM Z-score & Classific \\
\hline 1 & ACC & 1,50 & Distress & 1,05 & Distress & 12,78 & Safe & 9,07 & Safe \\
\hline 2 & BCE & 1,01 & Distress & 0,65 & Distress & 7,66 & Safe & 5,76 & Safe \\
\hline 3 & BT6 & 0,68 & Distress & 1,51 & Distress & 0,68 & Distress & 212,60 & Safe \\
\hline 4 & C47 & 0,76 & Distress & 0,47 & Distress & 5,50 & Safe & 5,17 & Safe \\
\hline 5 & $\mathrm{CDC}$ & 0,25 & Distress & 0,32 & Distress & 5,91 & Safe & 6,55 & Safe \\
\hline 6 & CIG & 0,30 & Distress & 0,42 & Distress & 7,19 & Safe & 4,19 & Safe \\
\hline 7 & CII & 0,09 & Distress & 0,29 & Distress & 3,28 & Safe & 4,82 & Safe \\
\hline 8 & CLG & 0,33 & Distress & 0,15 & Distress & 4,56 & Safe & 2,91 & Grey \\
\hline 9 & CTD & 1,37 & Distress & 1,58 & Distress & 8,20 & Safe & 7,52 & Safe \\
\hline 10 & CTI & 0,21 & Distress & 0,16 & Distress & 2,86 & Safe & 3,02 & Safe \\
\hline 11 & FCN & 0,77 & Distress & 0,62 & Distress & 6,14 & Safe & 5,71 & Safe \\
\hline 12 & HAS & 0,44 & Distress & 0,67 & Distress & 6,92 & Safe & 6,05 & Safe \\
\hline 13 & HBC & 0,73 & Distress & 0,61 & Distress & 4,10 & Safe & 4,25 & Safe \\
\hline 14 & HDG & 0,43 & Distress & 0,69 & Distress & 5,51 & Safe & 6,21 & Safe \\
\hline 15 & HTI & 0,19 & Distress & 0,15 & Distress & 3,89 & Safe & 4,17 & Safe \\
\hline 16 & HU1 & 0,66 & Distress & 0,98 & Distress & 4,60 & Safe & 5,04 & Safe \\
\hline 17 & HU3 & 0,54 & Distress & 0,55 & Distress & 5,81 & Safe & 5,21 & Safe \\
\hline 18 & LCG & 0,15 & Distress & 0,69 & Distress & 3,31 & Safe & 5,19 & Safe \\
\hline 19 & LGC & 0,49 & Distress & 0,16 & Distress & 5,82 & Safe & 6,25 & Safe \\
\hline 20 & LGL & 0,09 & Distress & 0,27 & Distress & 3,78 & Safe & 5,96 & Safe \\
\hline 21 & MDG & 0,47 & Distress & 0,43 & Distress & 4,10 & Safe & 2,42 & Grey \\
\hline 22 & PPI & 0,14 & Distress & 0,41 & Distress & 6,42 & Safe & 7,10 & Safe \\
\hline 23 & PTC & 0,31 & Distress & 0,37 & Distress & 6,31 & Safe & 7,51 & Safe \\
\hline 24 & PXI & 0,61 & Distress & 0,62 & Distress & 3,90 & Safe & 4,15 & Safe \\
\hline 25 & PXS & 0,66 & Distress & 1,01 & Distress & 4,24 & Safe & 5,06 & Safe \\
\hline 26 & PXT & 0,54 & Distress & 0,62 & Distress & 4,40 & Safe & 0,45 & Distress \\
\hline 27 & REE & 0,37 & Distress & 0,34 & Distress & 9,12 & Safe & 9,12 & Safe \\
\hline 28 & CS5 & 0,59 & Distress & 0,64 & Distress & 4,13 & Safe & 4,72 & Safe \\
\hline 29 & SRF & 0,79 & Distress & 0,91 & Distress & 7,49 & Safe & 6,28 & Safe \\
\hline 30 & UDC & 0,18 & Distress & 0,18 & Distress & 4,35 & Safe & 4,77 & Safe \\
\hline 31 & VNE & 0,44 & Distress & 0,65 & Distress & 3,68 & Safe & 6,37 & Safe \\
\hline 32 & VSI & 0,35 & Distress & 0,46 & Distress & 3,65 & Safe & 4,24 & Safe \\
\hline
\end{tabular}

Table 8: Results for 32 construction companies in Vietnam 


\begin{tabular}{|l|c|c|}
\hline Classification & Year 2013 & Year 2014 \\
\hline Distress Zone $(<1.81)$ & $32(100 \%)$ & $32(100 \%)$ \\
\hline Grey Zone $(1.81-2.99)$ & $0(0 \%)$ & $0(0 \%)$ \\
\hline Safe Zone $(>2.99)$ & $0(0 \%)$ & $0(0 \%)$ \\
\hline Total & $\mathbf{3 2 ( 1 0 0 \% )}$ & $\mathbf{3 2 ( 1 0 0 \% )}$ \\
\hline
\end{tabular}

Table 9: Result summary of Z-Score Model (Model 1)

\begin{tabular}{|l|c|c|}
\hline Classification & Year 2013 & Year 2014 \\
\hline Distress Zone $(<1.81)$ & $1(4 \%)$ & $1(4 \%)$ \\
\hline Grey Zone $(1.81-2.99)$ & $0(0 \%)$ & $2(6 \%)$ \\
\hline Safe Zone $(>2.99)$ & $31(96 \%)$ & $29(90 \%)$ \\
\hline Total & $\mathbf{3 2 ( 1 0 0 \% )}$ & $\mathbf{3 2 ( 1 0 0 \% )}$ \\
\hline
\end{tabular}

Table 10: Result summary of EM Z-Score Model (Model 2)

The summary of interpretation for Model 1 and Model 2 show the final results of the Z-Score and EM from 32 construction enterprises for the entire study period. Obviously, the results are different between the two models. With the sample of 32 construction enterprises, the Z-Score Model shows the high probability of insolvency of $100 \%$ adding to a Z-score $<1.81$ with high probability of bankruptcy. In contrast, the EM Z-score Model shows the high probability of business being sustainable with 31 companies in "Safe zone" in 2013, and started to decrease to 29 companies in 2014.

Statistically, the information taken from the CICB Credit database (The State Bank of Vietnam) has shown that the EM Z-Score Model describes the accurate financial distress information of construction firms in 2013 at 4\% and 10\% in 2014. This suggests that the EM Z-score Model can predict the probability of financial distress better in 2014 at around 6\%. Additionally, other construction enterprises in the safe zone in 2013 started to decline in the following year reflect the potential of financial difficulty. In other words, the EM Z-score Model measures the firms' financial performance more accurately and is well predicted over a short period of time. Furthermore, in consideration of each variable in the EM Z-score Model such as the Value of Equity/Total Liabilities, it is proved that the ratio should be positive in order to have better EM results. This indicates that in the construction industry, the more attractive market price the firms have, the better financial position they have. In other words, the stock market of a construction firm can affect its future sustainability. Consequently, by conducting analysis of the EM Z-Score model, companies can avoid potential distress by managing and using longterm assets more efficiently and effectively.

With Model 1, it seems to have no change in the companies' performance during the study period. The percentage of firms in distress still remains (at the point $<1.81$ ), which also means that none of these firms can escape from financial distress, while the information provided in Model 2 shows a high percentage of construction companies can actually survive at least in two years. Based on the Credit Information Center of Vietnam (State Bank of Vietnam), there are only two enterprises that are dealing with potential financial difficulty (BT6 and PXT). This reveals that the Vietnam Stock Market is completely different from Model 1.

Other than that, when it comes to the consideration of previous literature, the Value of Equity in Model 1 and Model 2 are based on totally different numbers. While Model 2 is based on the Book Value equity, Model 2 focuses more on the Market Value of Equity. In fact, Market Value of Equity cannot reflect the real condition of the company's performance. Recent years have 
witnessed a substantial down turn in the Vietnam stock market which resulted in the depreciation of $\$ 1.78$ Billion of market share. This indicates that the Vietnam stock market is not stable and in most cases, investment may be influenced by herding behavior in bullish and bearish markets (Vo and Phan, 2016).

Overall, the EM Z-score model is more compatible to investigate a company's financial performance in the Vietnam stock market than the Z-score as it enhances management's ability to predict potential financial distress. In addition, the EM Z-Score Model has a higher percentage of matching with the Vietnam Stock Exchange conditions. Since 2008, the Vietnam Stock Exchange has been unstably recovered from the massive drop down which has motivated investor's herding behaviors to purchase stocks. Moreover, the stock market in Vietnam is considered as an Emerging Market with low performance of financial management, lack of information transparency which is also affected by economy and the market system weakness (Dao and Tu 2014). Therefore, the EM Z-Score Model is an appropriate estimating instrument to predict the company's performance as it concentrates on the market credit risk in order to arrive at the final modified rating (Altman, 2005).

\section{Impact of other Financial Factors}

\section{FURTHER ANALYSIS}

After studying the correlation of Altman's two models to the financial performance of construction enterprises in Vietnam, we have shown that the EM Z-Score Model is a better model for answering the question whether a business is undergoing concern. However, other financial factors can also have an impact on the success of a firm. Is there any correlation between these financial factors and the financial ratio of the EM Z-score? To answer this question, the following five important factors will be examined to measure their significance to companies' performance and their correlation with Altman's EM Z-Score Model.

- Company Financial Growth can be defined as the mean of achieving higher value added and a goal of long-term survival of an organization. In other words, growth is the increase of sales revenue and value creation of assets. Growth can also affect business reputation in terms of market credibility. By increasing the revenue of products and services, firms can create a better reputation within the market that allows the process of expansion and acquisition. Furthermore, sustainable growth can create a strong financial condition which enhances the ability to compete with other opponents. On the other hand, the higher revenue implies that the investing strategies of an organization is on the right path, which can create more opportunities for success and long-term development.

$$
\begin{aligned}
R O A & =\frac{\text { Net Income }+ \text { Paid Interests }}{\text { Total Assets }} \\
R O E & =\frac{\text { Net Income }}{\text { Total Shareholders'Equity }}
\end{aligned}
$$

- Tangibility refers to the volume of a company's assets. In the construction industry, tangibility of an organization is also an important factor that ensures that businesses perform their project at high levels of efficiency and effectiveness. It is a combination of buildings, machines, and human resources. In the procurement process, it is by far most important to underline the existing assets available in stock that perfectly handle the construction package. In other words, a higher volume of tangibility the better corporate performance a company has. This is the case of the Vietnam construction industry when a larger firm may find it easier to win the package in procurement. 


$$
\text { FATA }=\frac{\text { Net Fixed Assets }}{\text { Total Assets }}
$$

- Cash Conversed Circle - the critical component which can define the success or failure of the construction industry. It measures the ability of a company's management to generate cash through the financing and investing process, in which, the efficiency and effectiveness of the enterprise will be calculated and expressed in the length of time to receive cash back. This calculation explains how fast management generates cash for a company. In the construction industry, more cash inflows in a short period of time means success in corporate performance. As the cash conversion cycle is an inclusive measure of management in accounts receivable, inventory and accounts payable, it is important that management should not ignore the significance of short term liabilities and current assets. Thus, management must take it seriously as a way to measure the risk and return of cash to overcome the failure of paying off current obligations of maturity assets.

$$
\begin{gathered}
D S O=\frac{\text { Accounts Receivable }}{\text { Total Credit Sales }} \times 365 \\
D S I=\frac{\text { Inventory }}{\text { Cost of Sales }} \times 365 \\
D P O=\frac{\text { Accounts Payable }}{\text { Cost of Sales }} \times 365 \\
C C C=\text { DSO }+ \text { DSI }- \text { DPO }
\end{gathered}
$$

- Size of the organization is the term of market capitalization volume. Statistically, it measures the quantity of sales and assets of a firm during its operation. In fact, a larger operation means the increase in market power and revenue creation. The size of an organization indicates not only the number of employees, the large volume of assets but also the control of market share. The larger size of an organization tends to affect other competitors in the same industry and even allowed them to acquire small firms that are not in competitive advantage. According to a previous study, the larger size of an organization is proven to be a positive sign to reduce the potential of bankruptcy, and higher growth rate indicates better performance of an organization (Nguyen and Nguyen 2015). However, the other side of market dominance is the reluctance to change in the corporate system when there is a change in customers' behavior and purchasing pattern. The story of Nokia corporation is an example of business failure in recognizing competition in a real market. Big companies have a tendency to ignore potential competitors as they are dominating the market.

- Debt ratio - The sum of Short-Term Debt and Long-Term Debt over Total Assets. They are the reflection of business obligation in the financing process in the short term such as a loan or accounts payable. A high level of Debt ratio means the negative effect on the organization when management failed to pay back mature liability to increase their return on investment. This is the financial risk when debt maturity cannot be paid off because of a company's poor investing and operating performance that cannot raise enough cash to pay regular interest and a lump-sum principle payment. A poor Debt ratio may indicate low performance of management to raise money or return on their investment. 


$$
D R=\frac{\text { Total Debt }}{\text { Total Assets }}
$$

\section{Empirical Results}

Table 4 shows the sample statistics of 32 construction companies. Overall, the mix of samples in 32 construction enterprises illustrate the significantly large number of Tangibility of 0.37 (37\%) which is acceptable as the average market value of the construction industry is rising constantly around $10 \%$ in 2015 with the volume of import material in 2016 of 32\% (Vietnam report, 2016). In addition, the average Growth rate is also another result of significant increase in growth of all study samples. The mean of growth is 3.81 which indicates that in two years the average sample firms have a growth of $381 \%$ in overall. The standard deviations are 28.46 and 1.15 for Growth and Tangibility respectively. Lastly, the average ROA in study sample is acceptable, however, this rate of return is still lower than the average market value which may not satisfy investor expectation. Standard deviation of ROA is 0.41 .

\begin{tabular}{lccc}
\hline & Mean & Std. Deviation & N \\
\hline Z-Score & 2.869568 & 12.771 & 64 \\
Growth & 3.816258 & 28.46548 & 64 \\
TANG & 0.373105 & 1.158528 & 64 \\
Debt & 0.642419 & 0.164601 & 64 \\
CCC & 338.4723 & 384.7222 & 64 \\
Size & 12.08023 & 0.392447 & 64 \\
ROA & 0.1219 & 0.41906 & 64 \\
\hline
\end{tabular}

Table 11: Sample's descriptive statistic and EM Z-Score

The mean of Debt ratio (Debt) at the average of 0.64 (64\%) demonstrates that there are a high number of construction companies using debt as a source of finance. In 32 samples of construction companies, there are 26 enterprises using debt orientation to finance their business. In the case such as Construction $47 \mathrm{Ltd}$. (C47), the proportion of debt used for financing its business was $90.48 \%$ and still remained the same pattern from 2013 to 2014 . There are only 6 out of 32 construction enterprises using equity as the main source of finance such as REE, ACC, PTC, HAS, CTD and LGC. They tend to keep the low debt in two consecutive years at the range from $20.08 \%$ to $47.09 \%$ in percentage of debts over assets.

The sample has an average size of 12.080 reflects the volume of Vietnam construction enterprises. This sample is acceptable as the range of Size is from 100 billion to 6.189 billion in terms of Net Credit Sales. However, the credit sales may cause financial risk as the Cash Converting Cycle (CCC) is deemed to be high at the mean of 338.47. The CCC sample restates that construction companies are struggling to pay off their debts and current interest because they have to wait 338.4 days to receive cash from financing. Finally, the standard deviation of Size and CCC are 0.392 and 384.72 respectively. 


\begin{tabular}{|l|r|}
\hline Growth & 0.006 \\
\hline TANG & 0.183 \\
\hline Debt & -1.332 \\
\hline CCC & $1.53 \mathrm{E}-05$ \\
\hline Size & 1.604 \\
\hline
\end{tabular}

Table 12: The regression from EM Z-Score

The regression coefficient of Growth, Tang, Debt, CCC and Size for Z-Score are 0.006, 0.183, $1.332,0.0,1.604$ respectively (see Table 5). This means that if Growth increased by $1 \%$ the Zscore will increase by $0.006,0.183,1.604$ and decrease by 1.332 . Although the final result shows the increase of most of the betas, however, this equation is not showing the significance of all the financing factors that can affect the result of the Z-score. Adjusting the R-Square has been taken to account which shows the insignificance of correlation between all financing factors within the equation and Z-score.

\section{Interpretations}

The regression shows that there is no correlation between Growth, ROA and business's performance, especially in the Vietnam construction industry. This finding may lead to the point that the increase in a firm's ROA and Growth is not necessary to have the increase in a firm's performance. As the result, this finding outlines the fact that a company's growth may be the result of external factors such as economic conditions, the tendency of urbanization, and changes in law, regulation in real estate and the construction industry (BMI Report, 2015). Firstly, the Vietnam economy in recent years has been stabilizing which enhances the growth of the construction industry. Vietnam's economy in 2015 and 2016 remained stable with a low inflation rate and interest rate, while consumer's consumption has been increasing over the period. This has positively boosted construction industry and the whole economy. Secondly, the tendency of urbanization is one of the foundations for the advance of a civilized construction sector. According to the World Bank (2012), Vietnam is urbanizing at the rate of $3.4 \%$ per year in two large economic centers, Hanoi and Ho Chi Minh City. That takes an important role in economic growth and reduction of poverty.

According to our analysis, Tangibility was insignificant in all cases of the regressions, while it takes a very high proportion of total assets in the study samples. In previous assumptions, tangibility is expected to be the most important factor of construction enterprise as it represents the capital investment that can generate revenue and income. However, the result from the regression analysis does not show any correlation between the size of a firm's assets and the company's performance. This has leads to the conclusion that tangibility may not affect the performance of construction enterprises at all.

The regression results in Table 2 show that Cash Conversion Cycle has a positive but insignificant impact on the Z-Score. Our analysis has also revealed an average of receivable collection period of 338 days. This result may signify the problem of a going concern in the construction industry where management has failed to deliver a short period of cash conversion. However, the regressions have concluded that cash conversion cycle is not an affecting factor to the change of Z-Score model and ROA. As the result, Vietnam construction enterprises are not stimulated by the factor of cash conversion cycle.

In a previous study, Size of a firm defines how much success management can be in the market. The larger the size of a firm means the higher the rate of return in investment. In our analysis, 
we found a positive relationship between size and EM Z-Score (see Table 5).

Based on sample statistics, there are over $43 \%$ of construction companies that have a Debt ratio of more than $70 \%$, the proportion of 35\% of construction firms have a Debt Ratio range between $50 \%$ to $70 \%$ and the remaining companies stay below $50 \%$. In normal business practice, the high rate of Debt ratio can raise problems for a profitable business if they cannot pay off the mature debt. However, it seems that this financial risk is not a considerable problem for 32 construction companies.

\section{CONCLUSION}

This paper analyzes the impact of Altman's Z-score and other financial factors on Vietnam's construction enterprises. Previous Altman's studies and others recognized the importance of the Z-Score formula to the failure or success of a firm. However, it is relevant to have a study of the construction industry in Vietnam in application of the Altman Z-score and other financial factors. As the Vietnamese market is considered as an emerging market, the study of Emerging Market Z-score has been used to compare and contrast with the original model. The results have approved the Emerging Market Z-score to be the more appropriate model for construction companies listed in the Vietnam stock exchange. Furthermore, some other important factors that can determine the well-being of corporate performance such as Tangibility, Growth, Size, Cash Conversion Cycle and Debt Ratio are also examined in the hypothesis regression. The hypothesis regression results have revealed that Tangibility, Growth, Size, Cash Conversion Cycle and Debt Ratio have no significant correlation with the Zscore equation. This also means that none of these factors can have either a positive or a negative impact on Vietnam Construction enterprises.

\section{References}

Altman, E. (1968), "Financial Ratio, Discriminant Analysis and The Prediction of Corporate bankruptcy”, The Journal of Finance, Vol. 23, pp. 589-609.

Altman, E. (2005), "An Emerging Market Credit Scoring System for Corporate Bond", Emerging Markets Review, Vol. 6, pp. 311-323.

Altman, E. (2013), "Predicting Financial Distress of Companies: Revisiting the Z-Score and ZETA Model”, Handbook of Research Methods and Applications in Empirical Finance, Edward Elgar Publishing, pp. 428-456.

Altman, E. and P. Narayanan (1977), "ZETA Analysis: A new model to identify Bankruptcy Risk of Corporation”, Journal of Banking and Finance, Vol. 1, pp. 29-51.

Beaver, H. (1966), “Financial Ratio as predictor of failure”, Journal Accounting Research, Vol. 4, pp.123-127.

BMI Report (2015), "Vietnam Investment Law to Boost Business Environment", Available at https://www.bmiresearch.com/articles/vietnams-investment-law-to-boost-business-environment

Chieng, J. (2013), "Verifying the Validity of Altman's Z" score as a Predictor of Bank Failure in the case of the Eurozone", Available at http://trap.ncirl.ie/865/

Dang, G and L. Pheng (2015), Infastructure Investment in Developing Economies - The Case of Vietnam, Springer Science + Business Media, Singapore.

Dao. B and N. Tu (2014), "Herding Behavior: Overview and Evidence in Vietnam Stock Market”, Available at SSRN: https://ssrn.com/abstract=2543723 or http://dx.doi.org/10.2139/ssrn.2543723

Enshassi, A. Al-Hallaq, K. and S. Mohamed (2006), “Causes of Contractor's Business Failure in Developing Countries: The Case of Palestine”, Journal of Construction in Developing Countries, Vol. 11(2), pp. 1-14.

Fisher. R A (1936), "Use of Multiple Measurement in Taxonomic Problems”, Annals of Eugenics, Vol. 7, pp. 179-188. McKay, A. (2016), “The Role of Automatic Stabilizers in the US Business Cycle”, Econometrica, Vol. 84, pp. 141-194. Mckee, T.E. (2000), "Developing a Bankruptcy prediction model via rough sets theory”, Intelligent Systems in Accounting, Finance and Management, Vol. 9(3), pp.159-173. 
Nguyen, T. and C. Nguyen (2015), “Capital structure and Firm’s Performance: Evidence from Vietnam's Stock Exchange", International Journal of Economics and Finances, Vol. 7(12), pp.1-10.

Ohlson, J.A. (1980), "Financial Ratios and the Probabilistic Prediction of Bankruptcy”, Journal of Accounting Research, Vol. 18, 109-131.

Pretorious, P. (2009), “Defining business decline, failure and turnaround: a content analysis”, The Southern African Journal of Entrepreneurship and Small Business Management, Vol. 2(1), pp. 1-16.

Siddiqui, S.A. (2012), “Business bankruptcy prediction model: A significant study of the Altman's Z-score Model”, Asian Journal of Management Research, Vol. 3(1), pp. 212-219.

Taffler, R.J. (1984), "Empirical model for the mornitoring of UK corporation”, Journal of Banking and Finance, Vol. 8 (2), pp. 199-227.

Torres-Coronas, T., A. Belzunegui-Eraso and J. Moreno-Gené (2015) “Finding solutions for a Post-Crisis Society: 1st International Virtual SBRLab Conference", Available at http://llibres.urv.cat/index.php/purv/catalog/book/169

Ucbasaran, D., D.A. Shepherd, A. Lockett and S.J. Lyon (2013), "Life after Business Failure: The Process and Consequences of Business Failure for Entrepreneurs”, Journal of Management, Vol. 39(1), pp. 163-202.

Vietnam Report (2016), “RLB Construction Market Update - Vietnam Q4 2016”, Available at http://rlb.com/en/index/publications/?filter-publication-type=Research\&filter-region=asia

Vo, X.V. and D.B.A. Phan (2016), "Herd Behavior in Emerging Equity Markets: Evidence from Vietnam”, Asian Journal of Law and Economics, Vol. 7(3), pp. 369-383.

Wong, J.M.W. and Ng, T.S.T. (2010), “Company failure in construction industry: a critical review and a future research agenda", Available at http://hub.hku.hk/handle/10722/127294

World Bank (2012), "Vietnam needs to seize its urbanization opportunities to become a middle income country", Available at http://www.worldbank.org/en/news/press-release/2012/04/05/vietnam-needs-to-seize-itsurbanization-opportunities-to-become-a-middle-income-country

Zmijewski, M.E. (1984), "Methodological issues related to the estimation of financial distress prediction model", Journal of Accounting research, Vol. 22, pp. 59-82. 